\title{
An Analisys of Passive Construction in Rempung Language East Lombok
}

\author{
Moh. Ismail Fahmi* \\ Postgraduate English Department \\ Universitas Mataram \\ Mataram Indonesia \\ rizkyfahita1@gmail.com
}

\author{
Amrullah Amrullah \\ Postgraduate English Department \\ Universitas Mataram \\ Mataram Indonesia
}

\begin{abstract}
The purpose of this research is to identify the forms of passive voice in Rempung language and to investigate whether the appearance $i$-prefix -form in the Rempung. This research was conducted at Rempung village. The design of the research is descriptive qualitative. The data collection method used is note taking as primary data while having conversation with people who are speaking Rempung as their native language. After all data were collected, then they were sorted based on the researcher's needs to be analyzed. The data analysis shows that the passive construction in Rempung Language is divided in two kinds. First passive construction use " $i$ " prefix but active and passive as same prefix (Inverted passive). eq. Tulis (write) $-i$ tulis passive and active $i$-tulis (is written), Second first passive construction use " $i$ " prefix passive and active is different (nonInverted). e.g. Tama (enter) infinitive, se-tama use in active and the passive construction become i-se-tama (is entered), se in second prefix has not meaningful but we should put down. In Indonesia Language, masuk (infinitive), me-masukkan (Active) and di-masukkan (Passive) it is called Non-Inverted. Rempung language is unique passive construction because more than passive construction in Rempung language dialect is Inverted than non-Inverted.
\end{abstract}

Keywords - passive, prefix, inverted, Rempung

\section{INTRODUCTION}

Rempung located in distric of Pringgasela East Lombok, West Nusa Tenggara. Most of them are sumbawa etnic. The language used in communication is the Sumbawa Taliwang but they have different dilaleq. But of course they understand and they can use Sasak language which is the majority etnic in Lombok island. they have unique language especially in passive construction. They have different varieties of language dialects (Rempung Pringgasela, Rempung Anjani, Jantuk and Kembang Kerang) in one community is a common practice. This reflects the efforts of the community members to make communication among them keep running. This practice occurs in open communities, where the members do not live exclusively from other communities. In this situation it is very likely that their cultures, including their languages. For open communities this condition will be readily accepted (or at least it can't be avoided or rejected). The real problem lies on the process where the members of the community struggle against the difficulty in understanding and using the new variety; the more distinct and complicated the new variety is, the more difficult the process will be.

\begin{abstract}
All along the period, people always learn language, because the language has crucial rule in the real life. It is imaginable, without language how the world will be. But probably for its customary, language is infrequently has not attention, and usually supposed as common things as human being walking or breathing. Language is not just spoken but also alliance by its rule, in this case syntax. Almost whole the educational institutions, which open program of Strata (S-1) of language, teach their students about linguistics. The knowledge of it is not as a requirement to fullfil the assignment merely, but it will be a provision in enriching the concepts about language, especially in high level. Syntax is one of the branches of linguistics that learns about sentence. Syntax holds crucial rule, for language that is used in communicating the contents of language itself.
\end{abstract}

The researcher is interested at knowing deeper about Rempung language as his first language, which he uses in daily activities, the researcher also wants to describe or explain a bit about Rempung language to the readers how to passivize Rempung language and what kind of passive construction in Rempung language.

This research is expected to be able to improve the researcher's knowledge in knowing the Rempung language passive construction in details, and also the researcher hopes a lot it is able to improve the readers' knowledge about Rempung language, especially on Rempung language in passive construction, and be able to apply its knowledge in the real life later.

\section{REVIEW OF THE RELATED LITERATURE}

In supporting this research, the researcher thinks it is very crucial to collect some books as references for this research. And in this chapter the researcher needs to discuss about; Language and Linguistics, language acquisition, language varieties, dialect, overview of dialect variation, classification of dialect, Review of the Related Literature In supporting this research, the researcher thinks it is very crucial to collect some books as references for this research. And in this chapter the researcher needs to discuss about; Language and Linguistics, language acquisition, language varieties, dialect, overview of dialect variation, classification of dialect, Rempung dialect, sentence, phrase, clause, word, passive construction, passive properties, previous of the research 


\section{A. Language and Linguistics}

Language, a system of conventional spoken, manual, or written symbols by means of which human beings, as members of a social group and participants in its culture, express themselves. The functions of language include communication, the expression of identity, play, imaginative expression, and emotional release. Many definitions of language have been proposed. Henry Sweet, an English phonetician and language scholar, stated: "Language is the expression of ideas by means of speechsounds combined into words. Words are combined into sentences, this combination answering to that of ideas into thoughts." The American linguists Bernard Bloch and George L. Trager formulated the following definition: "A language is a system of arbitrary vocal symbols by means of which a social group cooperates [1].

Language, a system of conventional spoken, manual, or written symbols by means of which human beings, as members of a social group and participants in its culture, express themselves. The functions of language include communication, the expression of identity, play, imaginative expression, and emotional release. Many definitions of language have been proposed. Henry Sweet, an English phonetician and language scholar, stated: "Language is the expression of ideas by means of speechsounds combined into words. Words are combined into sentences, this combination answering to that of ideas into thoughts." The American linguists Bernard Bloch and George L. Trager formulated the following definition: "A language is a system of arbitrary vocal symbols by means of which a social group cooperates [1].

Language is a means to communicate, it is a semiotic system. By that we simply mean that it is a set of signs. Its A sign is a pair consisting - in the words of Ferdinand de Saussure - of a signifier and a signified. We prefer to call the signifier the exponent and the signified the meaning. For example, in English the string /dog/ is a signifier, and its signified is, say, dog hood, or the set of all dogs. (I use the slashes to enclose concrete signifiers, in this case sequences of letters.) Sign systems are ubiquitous: clocks, road signs, pictograms - they all are parts of sign systems.

Language differs from them only in its complexity. This explains why language signs have much more internal structure than ordinary signs. For notice that language allows to express virtually every thought that we have, and the number of signs that we can produce is literally endless. Although one may find it debatable whether or not language is actually infinite, it is clear that we are able to understand utterances that we have never heard before. Every year, hundreds of thousands of books appear, and clearly each of them is new. If it were the same as a previously published book this would be considered a breach of copyright! However, no native speaker of the language experiences trouble understanding them (apart from technical books).

\section{B. Language Varieties}

When two or more people communicate with each other in speech, we can call the system of communication that they employ a code. In most cases that code will be something we may want to call a language [2]. Richards, J. et al. defines that language is 'the system of human communication by means of a structured arrangement of sounds (or their written representation) to form larger units, for examples morphemes, words, and sentences' [3].

In sociolinguistics, a variety, also called a lect, is a specific form of a language or language cluster. This may include languages, dialects, registers, styles, or other forms of language, as well as a standard variety. The use of the word "variety" to refer to the different forms avoids the use of the term language, which many people associate only with the standard language, and the term dialect, which is often associated with non-standard varieties thought of as less prestigious or "correct" than the standard [4]. Linguists speak of both standard and non-standard (vernacular) varieties [5]. "Lect" avoids the problem in ambiguous cases of deciding whether two varieties are distinct languages or dialects of a single language. Variation at the level of the lexicon, such as slang and argot, is often considered in relation to particular styles or levels of formality (also called registers), but such uses are sometimes discussed as varieties as well [4].

\section{Dialect}

Dialect is a system of language that is used by the community to differ from other community that used different of system event has closed relationship (Weijen: 63). Other definition is given by (Chaurand; 151) dialect is a real language that is utilizing on literature or it is still using on reference to middle age language. Dialect is caused by a few elements such as; politics, cultural, economic by Mielet [6].

All languages in the territory of Indonesia, besides Indonesian and foreign languages were allied the local language. Local languages are part of Indonesian culture that is still alive and should be cherished and preserved or conserved. One of the local language preservation efforts is to conduct research that will increase knowledge of language. One important research studies carried out is the study of kinship regional languages in Indonesia. Minangkabau language is one of the local languages in Indonesia spoken by Minangkabaunese from West Sumatera. In daily communication, Minangkabaunese use the Padang dialect, which is the dialect used in Padang as the result of combination of several dialects that exist in West Sumatera. Thus, it can be regarded as the standard dialect of Minangkabau. Although Minangkabaunese use the same language, Minangkabau language, but they still have some differences. Speakers who are separated by different areas are likely to have differences in vocabulary, speech differences, differences in dialect and sub dialect, or language differences. For example, the lexical differences based on geography in Minangkabau area can be seen between Indropuro in Pesisir Selatan and standard Minangkabau language.

\section{Over View of Dialect Variation}

Linguistics define dialect as mutually intelligible form of language that differ in a systematic way from each other [7]. Several sectors have been identified the determination of linguistic boundaries such as; political, cultural, social, historical, and religious. The presence of these factors may lead to mutually intelligibly of language in which language variation cannot be understood by speakers of any different language variety. 


\section{E. Classification of Dialect}

Considering the above factors, this may influence the variation of dialect. The dialect variation can be classified based on the existence of one or more of the above identified factors [8], applies that there are three different approaches to language classification, namely; genetic classification, linguistics typology, and area classification.

\section{F. Rempung Dialect}

Language of the entire world has dialect itself. The researcher finds the dialect that's used to communicate in Lombok, the geographical distribution of linguistics variable is shown in elaborates maps. One map may show the distribution of different pronunciation of vowel in a certain word. In this case, the dialect of geographers draw a line between the two areas that called isologues, it sometimes runs together for language distance, as two areas that show a number of clear differences, dialect geographers are branch of dialectology that learned about the relationship of the variety of language [9].

Rempung located in distric of Pringgasela East Lombok, West Nusa Tenggara. Most of them are sumbawa etnic. The language used in communication is the Sumbawa Taliwang but they have different dilaleq. But of course they understand and they can use Sasak language which is the majority etnic in Lombok island.

\section{G. Jantuk Dialect}

Jantuk is one of the village in distric of Sukamulia East Lombok, West Nusa Tenggara The dialect of Jantuk is the most used in Anjani, Rumbuk (Sakra), Kemang Kerang (Aikmel). That dialect is the same as Sumbawa Taliwang.

\section{H. Passive construction}

Passive can be describe as a counter part of active [10]. Both passive and active are semantically the same but syntactically different. The can be distinguished in the word orders and the markings on the verbs as well. Canonical passive takes a di-prefix on the verb and a preposition oleh before the initial subject (or the passive agent). It is often that the olehpreposition drops when the initial subject, which becomes -nya (glossed 3SG) citizen on the verb. Accidental Passives In this part of passive construction, especially on accidental passive of Sasak could be identified by notifying some prefix properties Inverted Passive, which the form prefix of verb in active may the same as in Passive verb.

\section{Passive Properties}

The characteristic of passive properties is given by Blake [10];

- Passive clause subject is derived from active clause object

- 2. On the basic passive clause agent construction is state as adjunct phrase and sometimes is deleted.

- 3. Passive verb predicate is signed by formality with marking passive.

\section{METHODOLOGY}

The method used in this research is descriptive qualitative, since the data taken needs to describe. The researcher tries to present about population from an expert Shenk stated that population is a number of people that have at least the same characteristic [11]. Then, in this research the researcher tries to emphasize the research is focused on the population with several considerations such as; age, education, gender, etc.

Qualitative and descriptive research methods have been very common procedures for conducting research in many disciplines, including education, psychology, and social sciences. These types of research have also begun to be increasingly used in the field of second language teaching and learning. The interest in such methods, particularly in qualitative research, is motivated in part by the recognition that L2 teaching and learning is complex. To uncover this complexity, we need to not only examine how learning takes place in general or what factors affect it, but also provide more in-depth examination and understanding of individual learners and their behaviors and experiences. Qualitative and descriptive research is well suited to the study of L2 classroom teaching, where conducting tightly controlled experimental research is hardly possible, and even if controlled experimental research is conducted in such settings, the generalizability of its findings to real classroom contexts are questionable. Therefore, Language Teaching Research receives many manuscripts that report qualitative or descriptive research.

The terms qualitative research and descriptive research are sometimes used interchangeably. However, a distinction can be made between the two. One fundamental characteristic of both types of research is that they involve naturalistic data. That is, they attempt to study language learning and teaching in their naturally occurring settings without any intervention or manipulation of variables. Nonetheless, these two types of research may differ in terms of their goal, degree of control, and the way the data are analyzed.

The goal of descriptive research is to describe a phenomenon and its characteristics. This research is more concerned with what rather than how or why something has happened. Therefore, observation and survey tools are often used to gather data [12]. In such research, the data may be collected qualitatively, but it is often analyzed quantitatively, using frequencies, percentages, averages, or other statistical analyses to determine relationships. Qualitative research, however, is more holistic and often involves a rich collection of data from various sources to gain a deeper understanding of individual participants, including their opinions, perspectives, and attitudes. Qualitative research collects data qualitatively, and the method of analysis.

\section{A. Research Design}

Analyzing passive voice in Rempung especially "Rempung" dialect is not easy, since Lombok has different form of dialect. Generally, in doing this research the researcher uses technique qualitative, for it tries to discuss or analyze the passive construction in Rempung language.

\section{B. Method of Collecting Data}

The source of information is the community of Rempung village, which called informants. The aimed of this method is at knowing the grammatical form of 
language that will appear on social interactions. And to discover the forms of passive construction, which appear in daily communication among the users of Rempung language. This method also helped the researcher in arranging the material more easily. Then the researcher took notes from the conversation. Beside that the researcher also used some articles of Rempung and the books that have relationship toward the data analysis.

\section{RESULTS AND DISCUSSION}

Traditionally, passive voice can be described as counter part of an active voice [10]. In the active sentences, the agent is marked as the subject (S) and the patient is as the object $(\mathrm{O})$, both by word order and the agreement of the subject and the verb.

TABLE I. PASSIVE VOICE AND ACTIVE VOICE

\begin{tabular}{|c|l|l|l|l|l|}
\hline Prefix & Verb & aktive & meaning & Passive & Meaning \\
\hline \multirow{7}{*}{$i, s e$} & tama & $\begin{array}{l}\text { Se- } \\
\text { tama }\end{array}$ & enter & $\begin{array}{l}\text { i-se- } \\
\text { tama }\end{array}$ & $\begin{array}{l}\text { Was } \\
\text { entered }\end{array}$ \\
\cline { 2 - 6 } & tunu & $\begin{array}{l}\text { Se- } \\
\text { tunu }\end{array}$ & sleep & $\begin{array}{l}\text { i-se- } \\
\text { tunu }\end{array}$ & $\begin{array}{l}\text { Was } \\
\text { slept }\end{array}$ \\
\cline { 2 - 6 } & telas & $\begin{array}{l}\text { Se- } \\
\text { telas }\end{array}$ & turn on & $\begin{array}{l}\text { i-se- } \\
\text { telas }\end{array}$ & $\begin{array}{l}\text { Was } \\
\text { turned on }\end{array}$ \\
\cline { 2 - 6 } & \multirow{7}{*}{ mate } & $\begin{array}{l}\text { Se- } \\
\text { mate }\end{array}$ & $\begin{array}{l}\text { is turn } \\
\text { off }\end{array}$ & $\begin{array}{l}\text { i-se- } \\
\text { mate }\end{array}$ & $\begin{array}{l}\text { Was } \\
\text { turning } \\
\text { on }\end{array}$ \\
\hline \multirow{7}{*}{$i$} & bere & i-bere & give & i-bere & $\begin{array}{l}\text { Was } \\
\text { given }\end{array}$ \\
\cline { 2 - 6 } & sule & i-sule & borrow & i-sule & $\begin{array}{l}\text { Was } \\
\text { borrowed }\end{array}$ \\
\cline { 2 - 6 } & kirim & $\begin{array}{l}\text { i- } \\
\text { kirim }\end{array}$ & send & $\begin{array}{l}\text { i- } \\
\text { kirim }\end{array}$ & Was sent \\
\cline { 2 - 6 } & terima & $\begin{array}{l}\text { i- } \\
\text { terima }\end{array}$ & receive & $\begin{array}{l}\text { i- } \\
\text { terima }\end{array}$ & $\begin{array}{l}\text { Was } \\
\text { received }\end{array}$ \\
\cline { 2 - 6 } & tutup & $\begin{array}{l}\text { i- } \\
\text { tutup }\end{array}$ & close & i-tutup & $\begin{array}{l}\text { was } \\
\text { closed }\end{array}$ \\
\cline { 2 - 6 } & tama & $\begin{array}{l}\text { Se- } \\
\text { tama }\end{array}$ & enter & $\begin{array}{l}\text { i-se- } \\
\text { tama }\end{array}$ & $\begin{array}{l}\text { Was } \\
\text { entered }\end{array}$ \\
\hline
\end{tabular}

\section{A. 'Se' with Active and " $i$ " with passive Construction}

Before dealing a lot to the ' $\mathrm{i}$ ' that is used to mark passive verb, the researcher presents some meaning of the ' $i$ ' to prevent the readers from misunderstanding or misinterpreting. The researcher found ' $i$ ' construction with different meaning in some sentences. Notice the function of ' $i$ ' bellow:

1) se' is use in Active form

Example;

- Inaq se-tama meja

Mother (3SG) enter (Act verb) the table NP Ibu memasukkan meja

- Bapak se-telas TV Father (3SG) turn on (Act verb) Television Ayah menghidupkan TV

2) ' $i$ ' is functioning as the passive marking on the verb

Notice each sentence bellow that shows the function of the ' $i$ ' as the passive marking, the function of ' $i$, $s e$ ' in passive

Example:

- Aiq i- tumpak ling Humairo Lalo ember
Water (GS) PASS-pour by phrase 3SG-poss 3SG PREP ADV.P-jar

"The water was poured by Humairo"

"Air di-tuang oleh humairo ke Ember"

- dila i-se-mate ling kakak the lamp was turned off by brother lampu di-matikan oleh kakak

B. “Ling” Construction

Aiq $i$ - tumpak ling Humairo Lalo ember

Water (GS) PASS-pour by phrase 3SG-poss PRON3SG PREP

"The water was poured by Humairo"

"Air $d i$-tuang oleh humairo ke Ember"

\section{The Form of Passive Construction}

After the researcher analyzed the form of passive construction in Rempung, the researcher found two kinds of passive, are:

- Inverted Passive, which the form prefix of verb in active may the same as in Passive verb.

- Non Inverted which the form of verb in active may be different as in Passive verb as canonical passive and Accidental Passives The word "data" is plural, not singular.

\section{Rempung Non Inverted Passives}

As in other languages of Indonesia; Sundanese for instance, to form passive voice is usually marked with prefix $d i$ - , but in Rempung it is commonly marked with prefix $i$ - in the verb. And it is followed by ling phrase and it is optional function, it is as equal as oleh phrase in Bahasa Indonesia or by phrase in English. Notice the examples bellow:

- Inaq se-tama meja

Mother (3SG) enters (Act verb) the table NP Ibu me-masukkan meja

- Meja i- se-tama ling inaq The Table (GS) is entered (Act verb) Mother (3SG) Meja di-masukkan oleh ibu

In the example $\mathrm{A}$ is marked for active sentence and $\mathrm{B}$ is marked for passive sentence. In sentence A Meja (table) is the object of the sentence, because it's followed verb Enter (memasukkan). The passive construction of se-tama is $i$-se-tama. And when it is in the passive sentence, meja itself is promoted into grammatical subject. And the subject inaq in active sentence is demoted into prep.phrase after ling phrase as given in the sentence B above.

\section{E. Inverted Passives}

In Rempung language, the verb of Inverted passive sometimes may raise in the same verb form between active and passive verb.

- A Rina $i$-sule buku (Active)

3SG Rina- Active-noun

Rina borrows a book (Active)

Rina meminjam buku (Active

- $\quad$ Buku $i$-sule ling Rina (Passive)

Promotion-Passive-Demotion Rina(agent)

A book is borrowed by Rina (Passive) 
Sebuah buku di pinjam oleh Rina (Passive)

In the example $\mathrm{A}$ is marked for active sentence and $\mathrm{B}$ is marked for passive sentence. In sentence A buku (book) is the object of the sentence, because it's followed verb borrow (meminjam), which may appear in the form of pinjam but the meaning will different. So, the passive construction of $i$-sule is $i$ - sule, passive and active have same verb. And when it is in the passive sentence, meja itself is promoted into grammatical subject. And the subject inaq in active sentence is demoted into. phrase after ling phrase as given in the sentence B above.

\section{CONCLUSION}

After considering the previous chapter, the researcher can come to the conclusion that the form of passive construction that found in Rempung are: Non-Inverted passives can be formed by putting the prefix $i$-se-. In the Inverted passives might be formed by putting prefix $i$ marked. passive construction in Rempung may be put those kinds of one or two prefix in the verb. In the passive construction, the direct object of the 'ling' construction is adjunct phrase. The verbal predicate gets the prefix / $i$ / that indicates passive construction. Where the agent is indicated with the phrase preposition of 'ling' or 'by' phrase then followed by a NP. The 'ling' phrase in the passive construction cannot be omitted In Rempung language to have a form of passive, there are some elements that could be considered in the sentences. First of all, passive on Rempung can be made by / $i$ / construction that is signed by verb marking. Secondly, passive could be made by 'ling' construction in adjunct phrase. Rempung language is unique passive construction because passive construction in Rempung language dialect is more than Inverted than non-Inverted.

\section{REFERENCES}

[1] B. Spolsky, Sociolinguistics, vol. 1. Oxford university press, 1998.

[2] R. Wardhaugh, An introduction to sociolinguistics, vol. 28. John Wiley \& Sons, 2011.

[3] A. Akmajian, A. K. Farmer, L. Bickmore, R. A. Demers, and R. M. Harnish, Linguistics: An introduction to language and communication. MIT press, 2017.

[4] N. Hanafi, Morphology. Mataram: Universitas Mataram, 2018.

[5] F. Febryan, R. Rusdi, and F. Fitrawati, "The dialectal comparison of Indropuro dialect and standard Minangkabaunese," E-Journal English Lang. Lit., vol. 6, no. 1, 2017.

[6] H. Mialet, "The 'righteous wrath'of Pierre Bourdieu," Soc. Stud. Sci., vol. 33, no. 4, pp. 613-621, 2003.

[7] A. Collinot and F. Mazière, Un prêt à parler: le dictionnaire. FeniXX, 1997.

[8] A. Henry, Belfast English and Standard English: Dialect variation and parameter setting. Oxford University Press on Demand, 1995.

[9] B. Lou Dubois, "Cultural and social factors in the assessment of language capabilities," Elem. English, vol. 51, no. 2, pp. 257-261, 1974.

[10] F. R. Blake, "Expression of case by the verb in Tagalog," $J$. Am. Orient. Soc., vol. 27, pp. 183-189, 1906.

[11] J. S. Shenk and M. O. Westerhaus, "Population definition, sample selection, and calibration procedures for near infrared reflectance spectroscopy," Crop Sci., vol. 31, no. 2, pp. 469474, 1991.

[12] M. D. Gall, W. R. Borg, and J. P. Gall, Educational research: An introduction. Longman Publishing, 1996. 